\title{
FINANSYZACJA JEDNOSTEK SAMORZĄDU TERYTORIALNEGO NA PRZYKŁADZIE MIAST METROPOLITALNYCH W POLSCE
}

\section{WPROWADZENIE}

Kryzys finansowy z pierwszej dekady XXI w. oraz jego skutki nie pozostały bez wpływu na funkcjonowanie jednostek samorządu terytorialnego (dalej: JST) w Polsce. Skutki kryzysu finansowego w samorządach lokalnych przejawiały się w pogorszeniu ich kondycji finansowej, która związana była m.in. z nadmiernym zadłużeniem, wzrostem kosztów obsługi zadłużenia i ograniczeniem dostępu do środków finansowych lub położeniem nacisku na oszczędności i zwiększeniem ryzyka finansowego. Elementy te wpisują się w proces finansyzacji wszystkich sfer gospodarki - zarówno w skali makroekonomicznej, jak i mikroekonomicznej. Finansyzacja współczesnych gospodarek jest procesem naturalnym i nieodwracalnym, który przejawia się powiąaniem podmiotów niefinansowych z podmiotami sfery finansowej. W rezultacie tego procesu może nastapić wzrost uzależnienia podmiotów funkcjonujących w sferze realnej od warunków panujących na rynkach finansowych ${ }^{1}$. Zjawisko to jest relatywnie nowym zagadnieniem badawczym w światowej i polskiej literaturze, a w odniesieniu do samorządu terytorialnego w Polsce pozostaje nadal problemem niejednoznacznym i niewystarczająco zbadanym. Przejawia się to np. brakiem definicji finansyzacji w JST oraz jasnego sposobu jej pomiaru.

Celem artykułu jest więc wypełnienie owej luki przez podjęcie w praktyczny sposób oceny tego procesu w JST w kontekście struktury ich bilansu oraz skali zadłużenia. Podmiotem badań były największe miasta w Polsce (metropolie) $)^{2}$. Miasta te, z uwagi na większe środki finansowe, które pozostają do ich dyspozycji oraz system wielu połączeń gospodarczych z sektorem publicznym i prywatnym, mogły najszybciej odczuwać skutki natężenia finansyzacji. Okres badawczy objął lata 2007-2017. Okres ten uwzględnia uwarunkowania funkcjonowania miast metropolitalnych wynikające $\mathrm{z}$ unijnej perspektywy finansowej w latach 2007-2013 oraz 2014-2020. Górna granica okresu badawczego była podyktowana dostępnością danych.

\footnotetext{
1 Remlein (2015).

${ }^{2}$ Badaniem objęto: Białystok, Bydgoszcz, Gdańsk, Katowice, Kraków, Lublin, Łódź, Poznań, Rzeszów, Szczecin, Warszawę oraz Wrocław.
} 
W przeprowadzonych badaniach przyjęto hipotezę, że zjawisko finansyzacji było obecne w działalności dużych miast w Polsce szczególnie w pierwszych latach po rozpoczęciu kryzysu finansowego.

Zjawisko finansyzacji w metropoliach oceniono za pomocą wskaźników obliczonych na podstawie informacji płynących ze skonsolidowanych bilansów, które corocznie publikowane są m.in. przez Ministerstwo Finansów. Metodyka badań zaczerpnięta została z proponowanych przez Łukasza Sochę ${ }^{3}$ narzędzi stosowanych do oceny finansyzacji podmiotów gospodarczych. Jednak z uwagi na dostępność danych zawartych w miejskich bilansach, zmodyfikowano przyjęte wskaźniki oraz wykorzystano jedynie trzy spośród pięciu wskaźników zaproponowanych przez autora. Były nimi wskaźniki finansyzacji: aktywów trwałych, aktywów obrotowych oraz pasywów. W kolejnym etapie badań ocenie poddano drugi z aspektów finansyzacji, którym jest zadłużenie. Jego skalę zbadano za pomocą czterech wskaźników, które w odniesieniu do wszystkich JST corocznie publikuje Ministerstwo Finansów.

\section{FINANSYZACJA W UJĘCIU LOKALNYM}

$\mathrm{W}$ gospodarce światowej od lat siedemdziesiątych XX w. ${ }^{4}$, na skutek globalizacji, liberalizacji oraz deregulacji przepływów kapitałowych, obserwowany jest dynamiczny rozwój rynków finansowych ${ }^{5}$. Współcześnie w Stanach Zjednoczonych oraz w wielu rozwiniętych krajach widoczna jest postępująca dominacja sfery finansowej nad sferą realna gospodarki ${ }^{6}$. Proces ten, zwany finansyzacja, doprowadził do szeregu przemian, zarówno w samym sektorze finansowym, jak i w innych segmentach gospodarki, i w rezultacie wpłyną na cała gospodarkę. Według najbardziej popularnej definicji finansyzacja oznacza rosnącą rolę rynków finansowych, bodźców finansowych, podmiotów oraz instytucji finansowych w funkcjonowaniu zarówno narodowej, jak i globalnej gospodarki ${ }^{7}$. Najważniejszym przejawem finansyzacji jest rosnący udział sektora finansowego i generowanych za jego pośrednictwem zysków w gospodarce ${ }^{8}$. W wyniku postępującej finansyzacji zwiększa się znaczenie czynników finansowych w działalności podmiotów funkcjonujących w sferze pozafinansowej, które często wypierają tradycyjnie prowadzoną działalność ${ }^{9}$.

W ostatnich latach w literaturze przedmiotu dużo miejsca poświęca się badaniom przejawów finansyzacji dostrzeganych $\mathrm{w}$ całych gospodarkach ${ }^{10}$, w po-

\footnotetext{
${ }^{3}$ Socha (2016).

${ }^{4}$ Spoz (2016): 271.

${ }^{5}$ Azkunaga, San-Jose, Urionabarrenetxea (2013): 79.

${ }^{6}$ Szunke (2014): 100; Fierla, Grygiel-Tomaszewska (2017): 14.

${ }^{7}$ Epstein (2005): 3.

${ }^{8}$ Lisek (2016): 123-124; Włodarczyk (2018): 95.

${ }^{9}$ Ratajczak (2017): 25.

${ }^{10}$ Ratajczak (2012); Gostomski (2014).
} 
szczególnych jej podmiotach, w tym przedsiębiorstwach ${ }^{11}$, gospodarstwach domowych ${ }^{12}$ oraz w życiu codziennym ${ }^{13}$. Finansyzacja skutkuje również zmianami w przebiegu cykli koniunkturalnych ${ }^{14}$ oraz w działalności sektora publicznego $0^{15}$. Na poziomie lokalnym tego sektora finansyzacja nie jest jeszcze zjawiskiem dostatecznie zbadanym ${ }^{16}$, co przejawia się przede wszystkim brakiem klarownej jego definicji oraz niejednorodnością pomiaru tego zjawiska.

Mając na uwadze, że proces finansyzacji ma przede wszystkim charakter makroekonomiczny i globalny, należy zauważyć, że samorządy lokalne maja swój pośredni, ale duży udział w tzw. rozprzestrzenianiu finansów na najniższym poziomie podziału administracyjnego. Dokonuje się to przez działania i regulacje dotyczące m.in. rynku nieruchomości, który jest aktualnie kluczowym motorem rynków finansowych. Duże i bezpośrednie znaczenie maja także decyzje finansowe samorządów w odniesieniu do sposobu realizacji ich zadań $^{17}$. W związku z tym oraz odnosząc się do najbardziej popularnej definicji finansyzacji zaproponowanej przez Geralda Epsteina ${ }^{18}$, finansyzację w ujęciu lokalnym można określić jako rosnący wpływ czynników finansowych na funkcjonowanie JST. Postępujące oddziaływanie motywów finansowych na podejmowanie decyzji JST zwiększa ich powiązanie z podmiotami funkcjonującymi na rynku finansowym. W warunkach finansyzacji gospodarki podstawowym kryterium decyzyjnym staje się zysk, a horyzont czasowy planowania jest skrócony do minimum ${ }^{19}$. W przypadku JST, które pełnią szczególnie istotne funkcje społeczne, działalność taka jest ryzykowna i może zagrażać bezpiecznemu oraz stałemu świadczeniu usług publicznych.

Punktem kulminacyjnym rozrostu rynków finansowych w gospodarce był kryzys finansowy z roku $2008^{20}$, który pogorszył także warunki funkcjonowania JST. Skutki te wymuszają na władzach lokalnych podejmowanie działań w celu zapewnienia swoim jednostkom odpowiedniej kondycji finansowej. Finansyzacja w JST obejmuje zatem konieczność dokonywania zmian w polityce władz lokalnych powstałych jako konsekwencja ogólnego kryzysu ${ }^{21}$. Zmniejszenie dochodów budżetowych gmin, powiatów i województw, z jednej strony generuje bowiem potrzeby oszczędnościowe, a z drugiej - poszukiwanie innych możliwości uzupełniania brakujacych środków. Do momentu wybuchu ostatniego kryzysu finansowego ekspansja długu nastapiła we wszystkich podmiotach: instytucjach finansowych, przedsiębiorstwach niefinansowych,

\footnotetext{
11 Spoz (2016); Socha, Urban (2018).

12 Kata, Chmiel (2017); Waliszewski (2016).

13 Gołębiowski (2017); Szunke (2014); Lewicka-Strzałecka (2015).

14 Małecki (2016); Szunke (2014): 100.

15 Aalbers (2019): 9.

16 Løding (2018): 1.

17 Gupta (2019): 1127.

18 Epstein (2005).

19 Rossmann, Greenfield (2006): 2.

20 Włodarczyk (2018): 95; Nölke (2017): 30.

21 Ostrowska (2013): 136-143.
} 
gospodarstwach domowych, rządach, a także władzach lokalnych ${ }^{22}$. W długim okresie, z uwagi na ograniczenie możliwości inwestycyjnych, finansyzacja w JST może doprowadzić do wielu negatywnych zjawisk, wśród których wskazuje się np. obniżenie jakości usług, funkcjonowanie na poziomie minimalnym, dobór personelu, wypalenie zawodowe, upowszechnienie patologii środowiskowych i zawodowych ${ }^{23}$.

Ostatni kryzys finansowy będący konsekwencją nadmiernej finansyzacji gospodarek ${ }^{24}$ wpłynął również na warunki funkcjonowania samorządów lokalnych, przejawiając się przede wszystkim w rosnacej roli kryteriów finansowych, ale także w innych zjawiskach, które mają charakter pierwotny i wtórny. Pierwotnym przejawem finansyzacji jest zmniejszenie się dochodów JST, które wynika z osłabienia siły podatkowej społeczeństwa oraz ponoszenia dodatkowych wydatków związanych z jego zubożeniem. Przejawy wtórne powstają natomiast na skutek polityki oszczędnościowej rządu. Konsekwencje finansyzacji można również podzielić na bezpośrednie i pośrednie. Skutki bezpośrednie dotyczą zmniejszenia transferów kierowanych do budżetów lokalnych oraz narzucanych przez szczebel centralny działań oszczędnościowych $\mathrm{w}$ formie reguł fiskalnych i limitów zadłużenia. Skutki pośrednie związane sa z finansowaniem dodatkowych zadań przekierowanych ze szczebla centralnego na lokalny, jak np. ulgi podatkowe, świadczenia dla nauczycieli, bez zwiększania środków dla JST ${ }^{25}$. Ostatecznym efektem finansyzacji jest zmniejszanie środków na finansowanie zadań JST. W ostatnich latach najsilniej skutki te dotknęły największe miasta, których dochody w dużej mierze są uzależnione od koniunktury gospodarczej ${ }^{26}$.

Wśród skutków zjawiska finansyzacji i kryzysu finansowego, a także zmian systemowych można wymienić: niską samodzielność finansową JST, zmiany wielkości i struktury wydatków budżetowych, pogorszenie wyniku finansowego i wzrost zadłużenia ${ }^{27}$.

Niedobór środków finansowych skłania władze lokalne do poszukiwania alternatywnych źródeł finansowania. W wyniku finansyzacji głównym źródłem pozyskiwania kapitału niezbędnego do finansowania podstawowych działań i dalszego rozwoju jednostek stają się rynki kapitałowe ${ }^{28}$, następuje skrócenie horyzontu inwestycyjnego ${ }^{29}$, a podstawowym motywem podejmowania decyzji staje się pieniądz oraz możliwości jego pomnażania ${ }^{30}$. Rosnące uzależnienie JST od sektora finansowego może powodować przenoszenie na nie dużej zmienności charakteryzującej ten sektor, a przez to działalność samo-

\footnotetext{
22 Fierla, Grygiel-Tomaszewska (2017): 37.

23 Bartkowski (2016): 57.

${ }^{24}$ Gostomski (2014): 299.

25 Bartkowski (2016): 40-41.

26 Poniatowicz (2014): 6.

27 Poniatowicz (2013): 338.

28 Szczepankowski (2016): 32.

${ }^{29}$ Marszałek (2012): 222.

30 Ratajczak (2014): 208.
} 
rządu może stać się bardziej ryzykowna ${ }^{31}$. Warto podkreślić, że finansyzacja JST może być zarówno szansa, jak i zagrożeniem. Zagrożenie wynika z konieczności redukcji wydatków, co może wpływać na pogorszenie jakości świadczonych usług przez JST lub nawet ich niewypełnienie. Z kolei szansa może być zmuszenie władz lokalnych do weryfikacji dotąd podejmowanych działań i poprawy ich efektywności ${ }^{32}$. Od władz lokalnych zależy, czy i w jakim stopniu motywy finansowe będą przejawiały się w funkcjonowaniu JST.

\section{FINANSYZACJA I JEJ POMIAR W MIASTACH METROPOLITALNYCH POLSKI}

Finansyzacja podmiotów gospodarczych, w tym także JST, przyjmuje dwie podstawowe formy: zmiany w udziale lub strukturze aktywów finansowych w relacji do posiadanych aktywów oraz rosnąca skala zadłużenia ${ }^{33}$. Jak wskazuje Piotr Szczepankowski, finansyzacja wiąże się z intensywnym poszukiwaniem dodatkowych dochodów, a to z kolei wywołuje bezpośrednie zmiany w sprawozdaniach finansowych jednostek ${ }^{34}$. Szczególne miejsce wśród tych sprawozdań mają bilanse i to właśnie m.in. w nich uwidacznia się zjawisko finansyzacji. Wynika to z tego, że jednym z przejawów finansyzacji jest zastępowanie aktywów rzeczowych aktywami finansowymi oraz nastawienie jednostek na generowanie zysków z działalności pozaoperacyjnej.

Jako miernik skali i rozwoju zjawiska finansyzacji zaproponowano trzy wskaźniki, które określono na podstawie dostępnych pozycji bilansowych ${ }^{35}$ w nawiązaniu do metodyki przedstawionej przez Sochę ${ }^{36}$. Były nimi:

- wskaźnik finansyzacji aktywów trwałych (WFat) mierzacy udział sumy inwestycji oraz środków przekazanych na inwestycje w środki trwałe w budowie, długoterminowych aktywów finansowych, długoterminowych należności finansowych (Xat) w sumie aktywów trwałych (Yat):

$$
W F a t=\frac{X a t}{Y a t}
$$

Rosnąca (malejąca) wartość wskaźnika (1) informuje o rosnącej (malejącej) roli inwestycji oraz aktywów finansowych w funkcjonowaniu miast, a więc o rosnącej (malejącej) skali finansyzacji.

\footnotetext{
31 Dziworska, Górczyńska (2017): 73; Remlein (2015): 169.

32 Bartkowski (2016): 41-42.

${ }^{33}$ Ratajczak (2012): 292; Dąbrowski, Fierla, Grygiel-Tomaszewska (2018): 73, 85.

34 Szczepankowski (2016): 32.

35 Ministerstwo Finansów (2018).

36 Socha (2016): 119-121.
} 
- wskaźnik finansyzacji aktywów obrotowych (WFao) mierzący udział sumy należności i roszczeń, należności finansowych krótkoterminowych oraz środków pieniężnych (Xao) w sumie aktywów obrotowych (Yao):

$$
W F a o=\frac{X a o}{Y a o} .
$$

Rosnąca (malejąca) wartość wskaźnika (2) oznacza postępującą (zwalniająca) finansyzację, która przejawia się w nastawieniu władz JST na krótkookresową (długookresowa) działalność, powiększającą (pomniejszająca) w krótkim czasie zysk,

- wskaźnik finansyzacji pasywów $(W F p)$ mierzący udział sumy zobowiązań krótkoterminowych i zobowiązań długoterminowych $(X p)$ w sumie pasywów $(Y p)$ :

$$
W F p=\frac{X p}{Y p}
$$

Rosnący udział zobowiązań w pasywach miasta świadczy o rosnącej dźwigni finansowej, która może prowadzić do maksymalizacji zysku z kapitału własnego oraz większej skali finansyzacji JST.

Dokonując oceny zjawiska finansyzacji w miastach metropolitalnych Polski przez pryzmat sprawozdań finansowych, w pierwszej kolejności zbadano strukturę aktywów trwałych tychże miast. Kształtowanie się median wskaźnika finansyzacji aktywów trwałych (WFat) w metropoliach przestawiono na wykresie 1.

\section{Wykres 1}

Kształtowanie się wartości środkowych wskaźnika finansyzacji aktywów trwałych (\%) w metropoliach Polski w latach 2007-2017

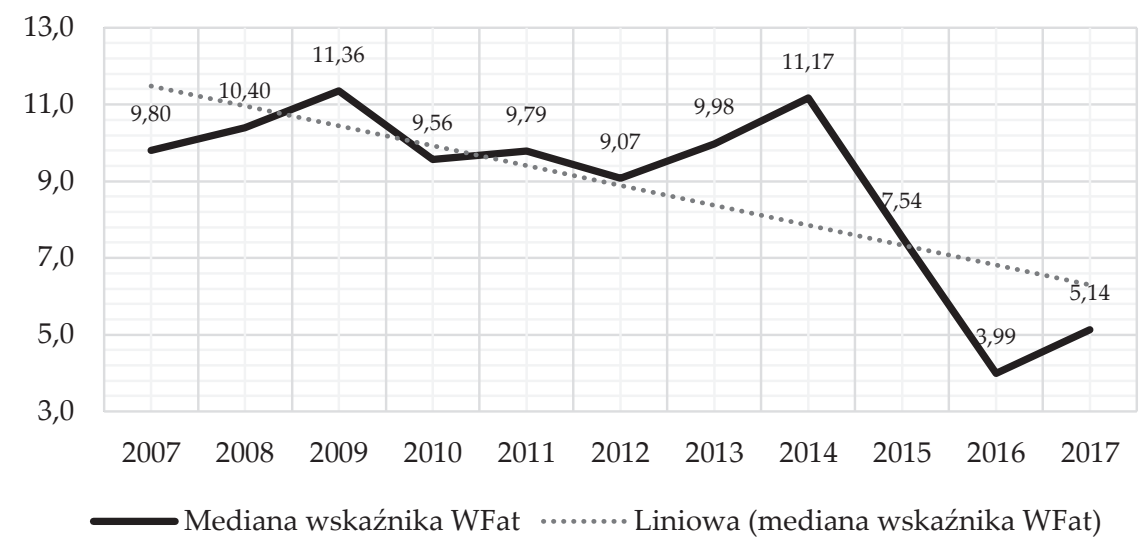

Źródło: opracowanie własne na podstawie danych Ministerstwa Finansów (2018). 
Wartość środkowa (mediana) wskaźnika finansyzacji aktywów trwałych we wszystkich metropoliach w latach 2007-2017 wynosiła 9,07\%. W początkowej fazie okresu badawczego rosła ona o niespełna 1 punkt procentowy rocznie, natomiast w latach 2009-2012 malała przy nieznacznym wzroście w 2011. W latach 2013-2014 wartość ta wzrosła do poziomu 11,17 punktu procentowego. W kolejnych latach nastapił znaczy jej spadek: w 2015 do 7,54\% i w 2016 do 3,99\%. W 2017 r. natomiast wzrosła do poziomu 5,14\%. W badanym okresie przeciętnie niskim poziomem wskaźnika WFat charakteryzowały się: Szczecin $(5,29 \%)$, Kraków $(5,74 \%)$ oraz Warszawa $(6,58 \%)$. Najwyższym natomiast poziomem odznaczały się metropolie: Wrocław (23,74\%), Łódź $(21,59 \%)$ oraz Gdańsk (13,19\%).

Jak wynika z wyznaczonej linii trendu wartości środkowej wskaźnika WFat, ogólna tendencja jej kształtowania się w okresie badawczym była malejąca. Można więc wnioskować o malejącej roli inwestycji i długoterminowych aktywów finansowych w funkcjonowaniu metropolii, co także może oznaczać mniejsze nasilenie finansyzacji w badanych jednostkach.

Wniosków tych nie potwierdzaja jednak w pełni badania przeprowadzone za pomoca kolejnego wskaźnika - finansyzacji aktywów obrotowych (WFao). Jego kształtowanie się w miastach metropolitalnych w latach 2007-2017 przedstawiono za pomocą median na wykresie 2 .

\section{Wykres 2}

Kształtowanie się wartości środkowych wskaźnika finansyzacji aktywów obrotowych (\%) w metropoliach w latach 2007-2017

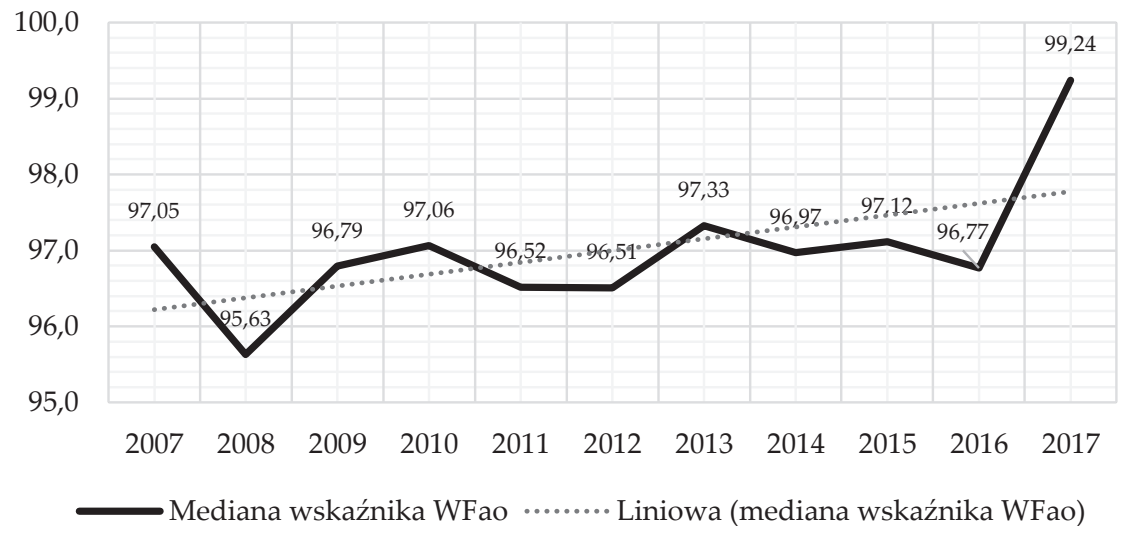

Źródło: opracowanie własne na podstawie danych Ministerstwa Finansów (2018).

Wartość środkowa wskaźnika finansyzacji aktywów obrotowych w latach 2007-2017 we wszystkich metropoliach wynosiła 97,02\%. W latach 2007-2016, poza rokiem 2008, w którym nastapił relatywnie duży spadek (o 1,5 punktu procentowego), wskaźnik ten utrzymywał się na stabilnym poziomie, a pasmo wahań nie przekroczyło 1 punktu procentowego. Dopiero w 2017 r. w porównaniu z latami poprzednimi nastapił jego znaczy wzrost do poziomu 99,24\%. 
W badanym okresie najwyższym średnim poziomem omawianego wskaźnika odznaczały się: Szczecin (99,17\%), Wrocław (97,72\%) i Łódź (97,19\%), natomiast najniższym - Katowice (88,81\%), Poznań (89,79\%) i Białystok (95,14\%). Jak wynika z linii trendu przedstawionej na wykresie 2, stopień finansyzacji aktywów obrotowych miał ogólną tendencję rosnącą w badanym okresie. Szczególnie wysokim poziomem wartości środkowej charakteryzował się ostatni rok okresu badawczego.

Z przedstawionej analizy można wywnioskować, że władze badanych miast mogły posiadać większą skłonność do akumulowania krótkookresowych aktywów finansowych, a więc ich decyzje finansowe mogły raczej przybierać perspektywę krótkookresowa. Z tego może wynikać także, że pojawiała się tendencja do utrzymywania środków finansowych na wypadek realizacji doraźnych celów jednostek. Zjawisko to należy ocenić jako negatywne w kontekście wychodzenia metropolii ze skutków kryzysu finansowego.

Ostatnim wskaźnikiem wziętym pod uwagę w badaniu stopnia finansyzacji metropolii na podstawie danych płynących z ich bilansów był wskaźnik finansyzacji pasywów. Kształtowanie się jego wartości środkowej w latach 2007-2017 przedstawiono na wykresie 3.

Wykres 3

Kształtowanie się wartości środkowych wskaźnika finansyzacji pasywów (\%) w metropoliach Polski w latach 2007-2017

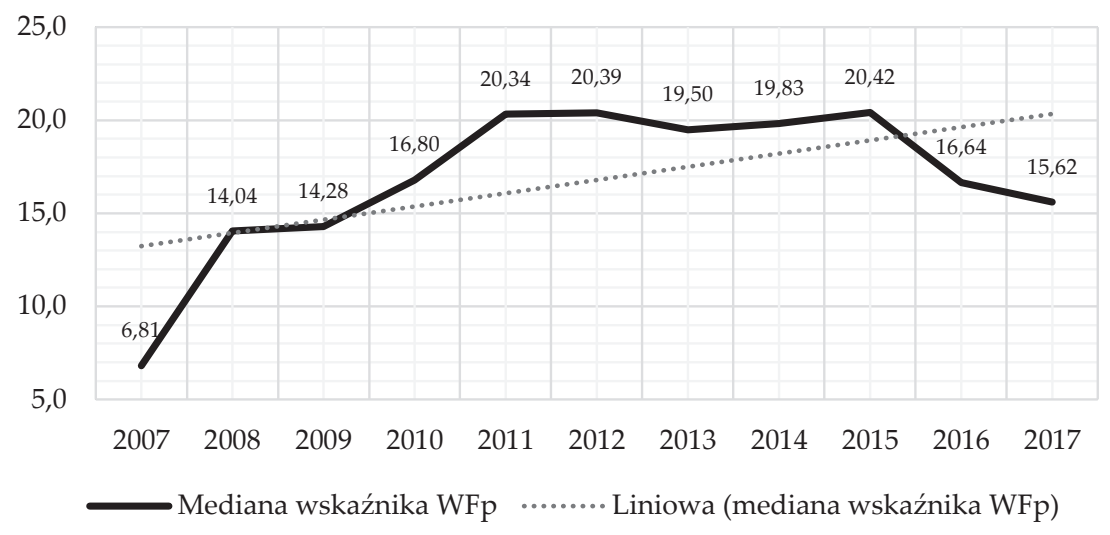

Źródło: opracowanie własne na podstawie danych Ministerstwa Finansów (2018).

Wartość środkowa wskaźnika finansyzacji pasywów metropolii w badanym okresie wynosiła $17,24 \%$. W pierwszych pięciu latach okresu badawczego wartość środkowa tego wskaźnika w metropoliach systematycznie rosła. W kolejnych trzech latach utrzymywała się na relatywnie stabilnym poziomie, po czym w roku 2016 i 2017 zaczęła maleć. W 2017 r. wyniosła 15,62\%.

Najwyższym średnim poziomem wskaźnika finansyzacji pasywów w badanym okresie charakteryzowały się: Łódź (38,30\%), Bydgoszcz (34,27\%) oraz Wrocław $(29,68 \%)$. Najniższy średni poziom omawianego wskaźnika odnotowano w Szczecinie (1,81\%), Krakowie (6,23\%) oraz Warszawie (10,13\%). 
Podobnie jak w przypadku poprzednio omawianego wskaźnika finansyzacji aktywów obrotowych, ogólna tendencja kształtowania się wskaźnika finansyzacji pasywów była rosnąca, na co wskazała linia trendu zaznaczona na wykresie 3. Może to oznaczać, że zadłużenie metropolii rosło (zwłaszcza w pierwszych latach badanego okresu). Późniejszy nieznaczny spadek wskaźnika może być skutkiem wprowadzenia w 2014 r. nowych reguł zadłużania się JST. Zjawisko to należy ocenić pozytywnie i można je także interpretować w kontekście ograniczenia kryzysu zadłużeniowego miast.

\section{ZADŁUŻENIE JAKO PRZEJAW FINANSYZACJI W MIASTACH METROPOLITALNYCH}

Zadłużenie JST powstaje wskutek emisji papierów wartościowych, zaciągania kredytów i pożyczek, przyjętych depozytów oraz zobowiązań powstałych w wyniku udzielonych gwarancji oraz poręczeń ${ }^{37}$. Możliwości zadłużania się JST mogą więc prowadzić do uwidocznienia się zjawiska finansyzacji jako rosnącego wpływu działalności finansowej na ich działalność. Problem skali zadłużenia JST, jak już wcześniej zauważono, jest szczególnie istotny z punktu widzenia usług świadczonych na rzecz społeczności lokalnej. Zbyt wysoki dług generowany przez JST stanowi bowiem zagrożenie dla stabilności finansów publicznych oraz całej gospodarki ${ }^{38}$.

Rosnące zadłużenie oraz upowszechniające się zjawisko finansyzacji w JST warunkowane jest przede wszystkim deficytem środków finansowych ${ }^{39}$. Zasób środków finansowych pozostających do dyspozycji JST jest często niewystarczajacy na pokrycie stawianych im zadań ${ }^{40}$, co stanowi impuls do poszukiwania nowych źródeł finansowania. Brak środków finansowych może mieć charakter doraźny (krótkoterminowy) lub trwały (długoterminowy, powyżej roku budżetowego $)^{41}$. W krótkim okresie zaciagany dług umożliwia finansowanie bieżących wydatków, w długim okresie - realizację inwestycji ${ }^{42}$. W literaturze wskazuje się, że dług zaciagany przez jednostki publiczne nie zawsze jest negatywnym zjawiskiem, a tzw. zły dług publiczny powstaje na skutek potrzeby finansowania wydatków bieżących. Natomiast „dobry” dług publiczny wynika z konieczności pokrywania długookresowych wydatków inwestycyjnych ${ }^{43}$. Ten ostatni motywowany jest korzyściami dla gospodarki, które przewyższaja koszty finansowania zobowiązań kredytowych ${ }^{44}$. Z kolei niemożność pokrywa-

\footnotetext{
37 Ustawa z 27 sierpnia 2009 r. o finansach publicznych, Dz. U. 2009, Nr 157, poz. 1240 ze zm.

38 Tetla (2016): 131.

39 Jastrzębska (2016): 189.

40 Kornberger-Sokołowska (2001): 50.

${ }^{41}$ Poniatowicz, Salachna, Perło (2010): 93-94.

${ }^{42}$ Kozera (2017): 206.

43 Waligóra (2013): 68.

44 Sawkowicz (2003): 5-7.
} 
nia wydatków bieżących przez JST oraz kumulacja zadłużenia w skali kilkuletniej wskazują na ich problemy z bieżącą płynnością finansową ${ }^{45}$.

Na ryzyko nadmiernego zadłużenia oraz upowszechnienia się zjawiska finansyzacji najbardziej narażone są duże miasta pełniące jednocześnie funkcje miast powiatowych oraz metropolii. Ten dualny charakter metropolii oraz duża liczba mieszkańców o różnorodnych potrzebach zmuszają władze lokalne do ponoszenia dużych kosztów zwiąanych z rozwojem infrastruktury technicznej oraz społecznej zaspokajającej potrzeby ludności nie tylko lokalnej, ale również zamieszkującej obszary metropolitalne ${ }^{46}$. Działania zmierzajace do poprawy infrastruktury realizowane w metropoliach zwiększają ich atrakcyjność inwestycyjna, przez co stanowią istotny czynnik lokalizacji inwestycji dla inwestorów zagranicznych. W takiej sytuacji metropolie zyskują znaczna przewagę konkurencyjną w walce o kolejnych inwestorów ${ }^{47}$.

Do czynników związanych z koniecznością zadłużania się JST w związku z inwestycjami, stanowiącymi jednocześnie przesłanki do upowszechnienia się zjawiska finansyzacji na szczeblu lokalnym, można zaliczyćc ${ }^{48}$ :

- zachowanie ciagłości międzypokoleniowej w dostępie do inwestycji,

- utrzymanie związku pomiędzy finansujacymi inwestycje i ich użytkownikami, który sprzyja efektywnej alokacji środków,

- korzyści z przyspieszonego rozwoju gospodarki przewyższające koszty obsługi kredytu,

- obniżenie bieżących kosztów funkcjonowania jednostki,

- wyższy koszt długookresowych inwestycji,

- stabilizacja środków budżetowych,

- dostęp do środków z Unii Europejskiej.

Podsumowując powyższe ustalenia, można wskazać, że zjawisko finansyzacji w miastach metropolitalnych odnosi się nie tylko do sfery finansowej i realnej, której przejawem jest zmieniająca się struktura sprawozdań finansowych tychże miast. Przejawia się ono także w rosnącym zadłużeniu, które zwiększa powiązania z instytucjami sektora finansowego. W przypadku zadłużenia w postaci kredytów oraz pożyczek czy wykorzystania tzw. pozabilansowych instrumentów finansowania, jak leasing oraz forfaiting, pogłębiają się powiązania z bankami oraz instytucjami pożyczkowymi.

Przy ocenie zadłużenia JST zastosowano wskaźniki zobowiązań według tytułów dłużnych, które proponuje Ministerstwo Finansów ${ }^{49}$. W'śród nich znajdują się cztery następujące:

- wskaźnik $W_{Z 1}$ - udział zobowiązań ogółem w dochodach ogółem;

- wskaźnik $W_{Z 3}$ - obciążenie dochodów ogółem obsługą zadłużenia, liczony jako stosunek odsetek od zaciagniętych kredytów i pożyczek oraz spłat rat kapitałowych od zaciagniętych kredytów i pożyczek do dochodów ogółem;

${ }^{45}$ Kozera (2017): 207.

${ }^{46}$ Kozera (2016): 71.

${ }^{47}$ Rynio (2010): 105.

48 Swianiewicz (2011): 157-159.

49 Ministerstwo Finansów, <https://www.finanse.mf.gov.pl/budzet-panstwa/finanse-samorzadow/opracowania> [dostęp: 27.11.2018]. 
- wskaźnik $W_{Z 5}$ - obciążenie dochodów własnych obsługą zadłużenia, liczony jako stosunek odsetek od zaciagniętych kredytów i pożyczek oraz spłat rat kapitałowych od zaciagniętych kredytów i pożyczek do dochodów własnych; łem.

- wskaźnik $W_{Z 7}$ - udział zobowiązań wymagalnych w zobowiązaniach ogó-

W kształtowaniu się przeciętnego wskaźnika udziału zobowiązań w dochodach ogółem $\left(W_{Z 1}\right)$ w latach 2007-2017 można wyróżnić dwa podokresy. W latach 2007-2012 wartości tego wskaźnika rosły, ale coraz wolniej, po czym od 2013 r. zaczęły stopniowo maleć. Ogólna tendencja wynikająca z linii trendu była jednak rosnacca, co mogło wynikać ze wzrostu zobowiązań powstałych na skutek współfinansowania inwestycji ze środków pochodzaçcych z Unii Europejskiej w ramach perspektywy finansowania 2007-2013. Można więc zaryzykować stwierdzenie, że finansyzacja w JST wiąże się w dużej mierze z kończącymi się Wieloletnimi Ramami Finansowymi.

Miastami o największym udziale zobowiązań w dochodach ogółem w badanym okresie były: Bydgoszcz (65,4\%), Łódź (64,7\%) oraz Wrocław (64,2\%), a najniższym poziomem tego wskaźnika charakteryzowały się Katowice (34,6\%), Białystok (44,1\%) oraz Warszawa $(46,2 \%)$.

\section{Wykres 4}

Kształtowanie się wartości środkowych wskaźnika udziału zobowiązań w dochodach ogółem w metropoliach Polski w latach 2007-2017

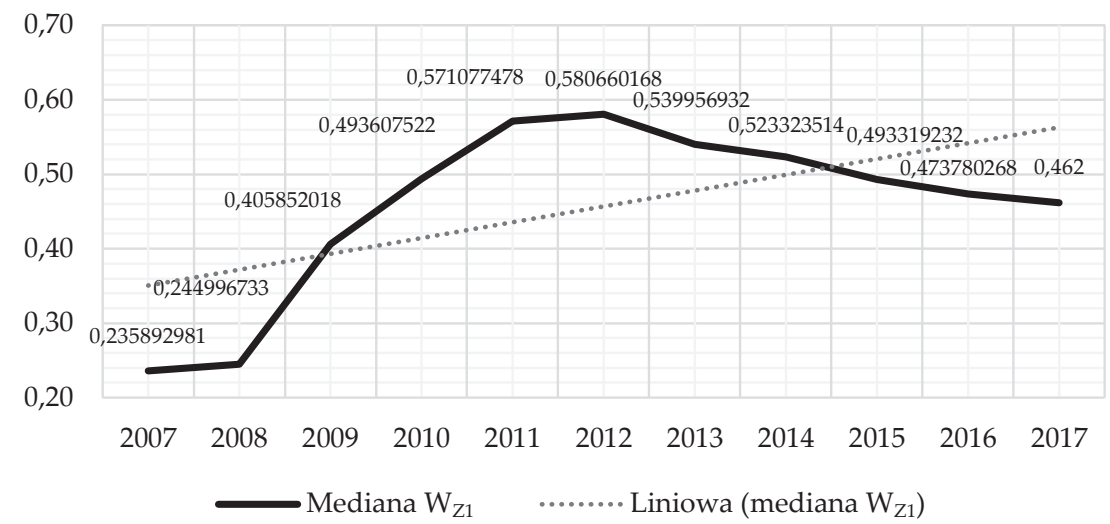

Źródło: opracowanie własne na podstawie Ministerstwo Finansów, Wskaźniki do oceny sytuacji finansowej jednostek samorządu terytorialnego w latach 2011-2013, Warszawa 2014; Ministerstwo Finansów, Wskaźniki do oceny sytuacji finansowej jednostek samorządu terytorialnego w latach 2014-2016, Warszawa 2017; Ministerstwo Finansów, Wskaźniki do oceny sytuacji finansowej jednostek samorządu terytorialnego w latach 2015-2017, Warszawa 2018.

Kolejnym analizowanym wskaźnikiem było obciążenie dochodów ogółem obsługa zadłużenia $\left(W_{Z 3}\right)$. Wskaźnik ten jest powiązany ze wskaźnikiem $W_{Z 1}$. $\mathrm{W}$ jego kształtowaniu się dostrzec więc można podobne tendencje. Mediana tego wskaźnika dla badanych miast wzrosła z poziomu 5,8\% w $2007 \mathrm{r}$. do $8,6 \%$ w 2012, po czym zaczęła stopniowo maleć, osiagając 5,0\% w 2017. 
Pozwala to ponownie na wyodrębnienie dwóch podokresów. Wzrost udziału zobowiązań w dochodach ogółem w latach 2007-2012 skutkował wzrostem obciążenia dochodów ogółem obsługą zadłużenia, a spadek tego udziału w latach 2012-2017 spowodował spadek drugiego analizowanego wskaźnika. Jednak ogólna tendencja wynikająca z linii trendu wskazuje na nieznaczny wzrost tego wskaźnika.

Najwyższym poziomem wartości środkowej (mediany) wskaźnika obciążenia dochodów ogółem obsługa zadłużenia w badanym okresie charakteryzował się Kraków (10,4\%), Wrocław (9,7\%) oraz Łódź (9,6\%), a najniższym, podobnie jak w przypadku pierwszego analizowanego wskaźnika, Katowice $(1,7 \%)$, Szczecin $(3,0 \%)$ oraz Warszawa $(4,6 \%)$.

Podobnie jak w przypadku poprzednio omawianego wskaźnika, należy uznać, że malejące udziały kosztów zadłużenia w dochodach ogółem świadczyły o mniejszym nasileniu zjawiska finansyzacji.

\section{Wykres 5}

Kształtowanie się wartości środkowych wskaźnika obciążenia dochodów ogółem obsługa zadłużenia w metropoliach Polski w latach 2007-2017

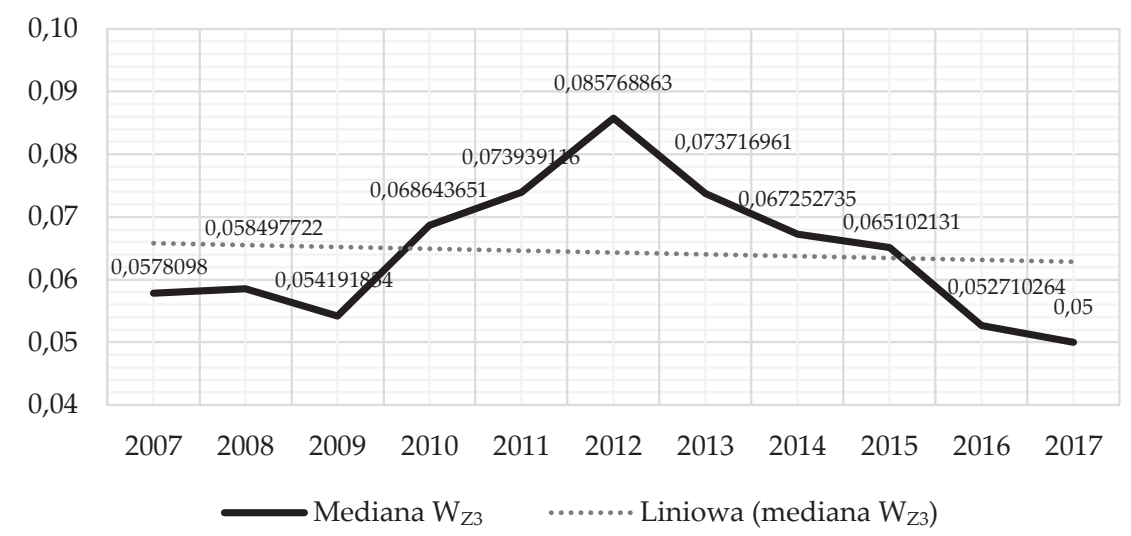

Źródło: jak na wykresie 4.

Wskaźnikiem, który odnosi koszty obsługi zadłużenia do dochodów własnych miasta, jest wskaźnik $W_{z 5}$. Wśród dochodów własnych gmin można wyróżnić: dochody z tytułu podatków i opłat lokalnych, udziały w podatkach państwowych od osób fizycznych i prawnych oraz inne źródła (np. kary, odsetki, darowizny). Mają one decydujący wpływ, jeśli chodzi o samodzielność finansową gmin. Koszty zadłużenia mogą zatem mieć ograniczający wpływ na samodzielność finansową miast. W badanym okresie w miastach metropolitalnych występowała ogólna nieznacznie malejąca tendencja w zakresie kształtowania się wartości średniej (mediany) poziomu wskaźnika obciążenia dochodów własnych obsługa zadłużenia, na co wskazuje linia trendu (wykres 3). W latach 2008-2011 nastapił wzrost tego wskaźnika z poziomu 8,4\% do 13,5\%. Od 2012 r. następował 
jego spadek do poziomu 7,8\% w 2017 r. Spadek tego wská́nika jest korzystny z punku widzenia sytuacji finansowej miast metropolitalnych.

Najwyższą wartość środkową (medianę) tego wskaźnika zaobserwowano w Krakowie (15,3\%), Łodzi (14,6\%) oraz Białymstoku (14,2\%) i Poznaniu (14,2\%), a najniższą w Katowicach $(2,4 \%)$, Szczecinie $(4,9 \%)$ oraz Warszawie $(6 \%)$.

\section{Wykres 6}

Kształtowanie się wartości środkowych wskaźnika obciążenia dochodów własnych obsługa zadłużenia w metropoliach Polski w latach 2007-2017

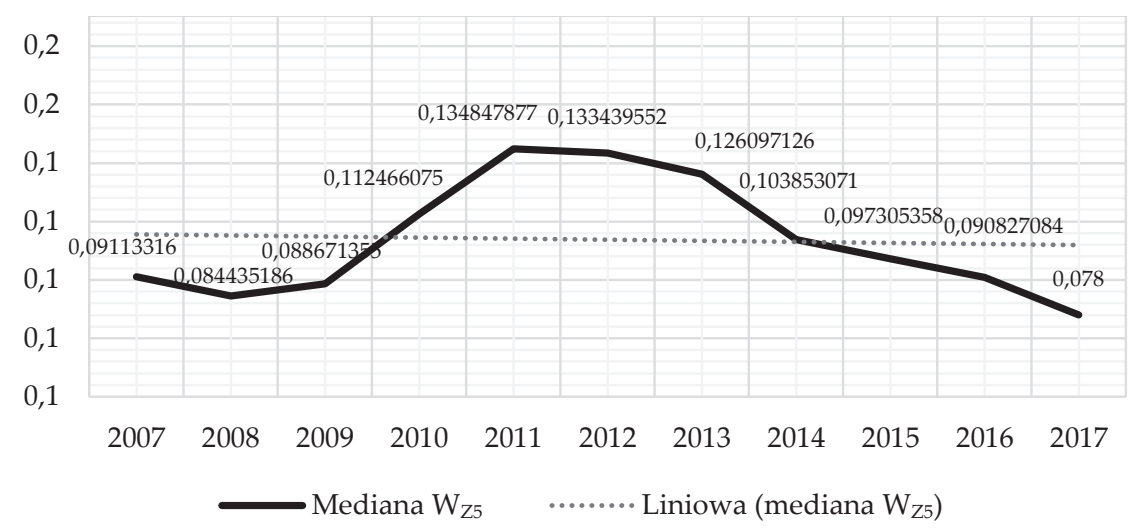

Źródło: jak na wykresie 4.

Wskaźnik $W_{Z 7}$ odnoszący zobowiązania wymagalne do zobowiązań ogółem informuje o udziale wszystkich zobowiązań łącznie z odsetkami, których termin płatności upłynął, a które nie są przedawnione lub umorzone ${ }^{50}$, w zobowiązaniach ogółem. Niskie poziomy tego wskaźnika można interpretować jako pozytwną sytuację, a więc mniejszą skalę zjawiska finansyzacji w badanych jednostkach. W miastach metropolitalnych przeciętny poziom omawianego wskaźnika z roku na rok malał (wykres 4). Nieznaczny wzrost odnotowano jedynie w roku 2009, kiedy wskaźnik ten wzrósł o 0,002\%, i ponownie w roku 2013 о $0,002 \%$.

Najwyższy średni poziom mediany udziału zobowiązań wymagalnych w zobowiązaniach ogółem odnotowano w Szczecinie (0,5\%), Łodzi (0,4\%) oraz Krakowie $(0,2 \%)$, natomiast najmniejszy - zerowy w Bydgoszczy i Lublinie. Tak niska wartość analizowanego wskaźnika w miastach metropolitalnych świadczy o braku negatywnych konsekwencji zjawiska finansyzacji w postaci nadmiernego zadłużenia oraz ryzyka niewypłacalności.

${ }^{50}$ Encyklopedia Gazety Prawnej - Forsal: <https://forsal.pl/finansopedia/bankowosc/hasla/ 911597,zobowiazania-wymagalne.html> [dostęp: 9.01.2019]. 


\section{Wykres 7}

Kształtowanie się wartości środkowych wskaźnika udziału zobowiązań wymagalnych w zobowiązaniach ogółem w metropoliach Polski w latach 2007-2017

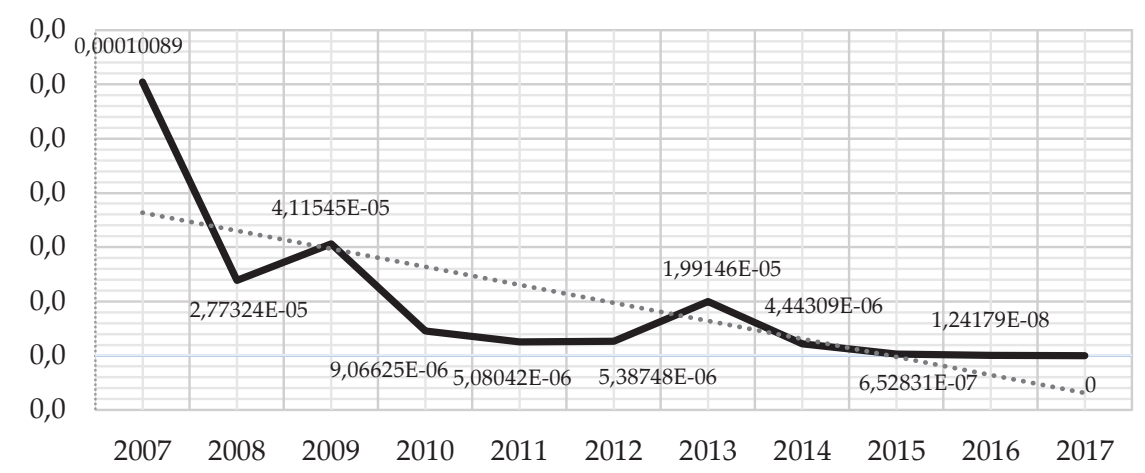

$\longrightarrow$ Mediana $\mathrm{W}_{\mathrm{Z7}} \quad$ ….... Liniowa (mediana $\mathrm{W}_{\mathrm{Z} 7}$ )

Źródło: jak na wykresie 4.

\section{ZAKOŃCZENIE}

Jak wynika z przeprowadzonych badań, zjawisko finansyzacji było obecne $\mathrm{w}$ miastach metropolitalnych Polski podczas kryzysu finansowego oraz w pierwszych latach po kryzysie, co nałożyło się z koniecznością dokonywania inwestycji współfinansowanych ze środków UE w ramach kończącej się perspektywy finansowej lat 2007-2013. Można wnioskować zatem o dużej współzależności pomiędzy poziomem narodowym oraz lokalnym finansów publicznych, jednakże w przypadku badanych miast skutki kryzysu były opóźnione. Oznaką tego zjawiska były wysokie średnie wskaźniki finansyzacji aktywów trwałych i obrotowych w poczatkowych latach okresu badawczego oraz równoczesny rosnący średni wskaźnik finansyzacji pasywów. W przypadku zadłużenia miast metropolitalnych zaobserwowano podobne tendencje. W drugiej części okresu badawczego (od około 2012-2013) sytuacja ta zaczęła się stopniowo poprawiać. Wartości środkowe poszczególnych badanych wskaźników zmalały. Wyjątek stanowią wskaźniki finansyzacji aktywów trwałych i obrotowych, których wartości nieznacznie wzrosły. Interpretacja tej zmiany będzie jednak możliwa w dłuższej perspektywie czasowej.

W związku z powyższym przyjęta hipoteza badawcza została zweryfikowana pozytywnie. Zaobserwowane ogólne tendencje w kategoriach bilansowych oraz skali zadłużenia należy oceniać pozytywnie z punktu widzenia prawidłowej gospodarki finansowej miast metropolitalnych, ponieważ mogą świadczyć o zażegnywaniu negatywnych skutków kryzysu finansowego oraz o coraz mniejszej skali procesu finansyzacji w większości miast metropolitalnych. Do miast, w których wartości środkowe omawianych wskaźników przyjęły najwyższą wartość, należą Łódź oraz Wrocław, a najniższą - Warszawa oraz 
Szczecin. W tej pierwszej grupie miast istnieją warunki do szybszego rozwoju procesu finansyzacji, a w drugiej jego rozwój jest mniej prawdopodobny.

Jak jednak wynika z przeprowadzonych studiów literaturowych, przy ostatecznej ocenie wskazanych tendencji należy wziaćc pod uwagę także inne czynniki. Oprócz dbałości o finanse miejskie szczególnie istotna z punktu widzenia mieszkańców miast może być równoczesna dbałość władz miejskich o wypełnianie powierzonych im zadań publicznych, a także o jakość świadczonych usług publicznych na jednakowym, nie gorszym niż wcześniej poziomie.

W związku z powyższymi uwagami nasuwa się także wniosek, że finansyzacja JST jest zjawiskiem skomplikowanym. Jej skutki odzwierciedlane są nie tylko w budżecie jednostek samorządowych - zwłaszcza w pozycjach dotyczących długu i kosztów jego obsługi, a także w strukturze bilansu. Ponadto moga być dostrzegalne w kierunkach i celach polityki finansowej prowadzonej przez władze miejskie oraz w powszechnie obowiąujacych przepisach prawa. Przy ocenie finansyzacji powinno się brać pod uwagę także czynniki o charakterze niemierzalnym. Zagadnienie to może stanowić przyszłe wyzwanie badawcze w dalszych analizach tego zjawiska. Ciekawym kierunkiem dalszych badań mogłaby być także analiza porównawcza i pomiar finansyzacji gmin wiejskich, w których można spodziewać się mniejszej skali zjawiska finansyzacji na tle miast.

Aleksandra Ostrowska

Uniwersytet Warmińsko-Mazurski w Olsztynie

aleksandra.ostrowska@uwm.edu.pl

https://orcid.org/0000-0001-5814-0530

Anna Wichowska

Uniwersytet Warmińsko-Mazurski w Olsztynie

anna.wichowska@uwm.edu.pl

https://orcid.org/0000-0003-2862-4424

Aalbers, M.B. (2019). Financialization, [w:] R. Richardson et al. (eds.), The International Encyclopedia of Geography: People, The Earth, Environment, and Technology. Oxford: Wiley: 1-14.

Azkunaga, J.A., San-Jose, L., Urionabarrenetxea, S. (2013). The impact of financial globalization and financialization on the economy in the current crisis through banking corporate governance. Contemporary Economics 7(3): 79-94.

Bartkowski, J. (2016). Finansjalizacja i samorząd terytorialny, [w:] A. Gemzik-Salwach, K. Opolski (red.), Finansjalizacja - wpływ na gospodarkę i społeczeństwo. Warszawa: CeDeWu: $39-58$.

Dąbrowski, T.J., Fierla, A., Grygiel-Tomaszewska, A. (2018). Pomiar finansjeryzacji Próba konceptualizacji. Warszawa: Oficyna Wydawnicza SGH.

Dziworska, K., Górczyńska, A. (2017). Współczesne dylematy poszukiwania nowego ładu gospodarczego. Współczesna Gospodarka 2: 71-86.

Epstein, G. (2005). Introduction: Financialization and the world economy, [w:] G. Epstein (ed.), Financialization for the World Economy. Northampton-Cheltenham: Edward Elgar: 3-28.

Fierla, A., Grygiel-Tomaszewska, A. (2017). Proces finansjeryzacji, [w:] Finansjeryzacja gospodarki i jej wpływ na przedsiębiorstwa. Warszawa: Oficyna wydawnicza SGH: 13-98.

Gołębiowski, G. (2017). Finansyzacja życia codziennego, [w:] J. Ickiewicz, J. Ostaszewski (red.), Złota Księga dla Profesora Jana Konstantego Szczepańskiego. Warszawa: Oficyna Wydawnicza SGH: 109-118. 
Gostomski, E. (2014). Finansyzacja w gospodarce światowej. Biznes Międzynarodowy w Gospodarce Globalnej 33: 299-311.

Gupta, P.S. (2019). The entwined futures of financialisation and cities. Cambridge Journal of Economics 43(4): 1123-1148.

Jastrzębska, M. (2016). Zadłużanie się jednostek samorządu terytorialnego w parabankach przyczyny, skutki, przeciwdziałanie. Ekonomiczne Problemy Usług 125: 187-200.

Kata, R., Chmiel, J. (2017). Household financialization-sense and scale of this phenomenon on the example of Poland. Financial Internet Quarterly "e-Finanse" 13(2): 62-74.

Kornberger-Sokołowska, E. (2001). Decentralizacja finansów publicznych a samodzielność finansowa jednostek samorządu terytorialnego. Warszawa.

Kozera, A. (2017). Rosnące zadłużenie jednostek samorządu terytorialnego jako zagrożenie dla rozwoju lokalnego. Nierówności Społeczne a Wzrost Gospodarczy 49: 203-215.

Kozera, A. (2016). Zadłużenie metropolii w Polsce w latach 2007-2013. Studia Regionalne i Lokalne: 70-93.

Lewicka-Strzałecka, A. (2015). Kultura finansjalizacji. Prakseologia 157/2: 209-230.

Lisek, S. (2016). Finansyzacja w małopolskich spółkach giełdowych i jej zmiana w czasie. Finanse, Rynki Finansowe, Ubezpieczenia 4: 123-132.

Løding, T.H. (2018). The financialization of local governments - the case of financial rationality in the management of Norwegian hydroelectric utilities. Socio-Economic Review 0(0): 1-19.

Ładysz, I. (2012). Wybrane aspekty zarządzania bezpieczeństwem finansowym i zadłużeniem miasta Wrocławia. Rocznik Bezpieczeństwa Międzynarodowego 6: 15-29.

Małecki, W. (2016). Finansjalizacja cykli koniunkturalnych i jej konsekwencje dla polityki stabilizacyjnej. Gospodarka Narodowa 4: 47-68.

Marszałek, P. (2012). Finansyzacja - problemy i kontrowersje. Prace Naukowe Uniwersytetu Ekonomicznego we Wrocławiu 247: 220-230.

Ministerstwo Finansów (2018). < https://www.mf.gov.pl/ministerstwo-finansow/dzialalnosc/finanse-publiczne/budzety-jednostek-samorzadu-terytorialnego/sprawozdania-finansowe>. [dostęp: 24.08.2018].

Nölke, A. (2017). Financialisation as the core problem for a "Social Europe". Revista de economia mundial 46: 27-48.

Ostrowska, M. (2013). Finansjalizacja: zarys problematyki. Rola Informatyki w Naukach Ekonomicznych i Społecznych: 136-143.

Poniatowicz, M. (2013). Finanse samorządu terytorialnego w warunkach niestabilnego otoczenia (na przykładzie miast Unii Metropolii Polskich). Zarządzanie i Finanse 11(2.3): 337-348.

Poniatowicz, M. (2014). Wpływ kryzysu gospodarczego na systemy finansowe jednostek samorzadu terytorialnego na przykładzie największych miast w Polsce. Warszawa: CeDeWu.

Poniatowicz, M., Salachna, J.M., Perło, D. (2010). Efektywne zarządzanie w jednostce samorządu terytorialnego. Warszawa: Wolters Kluwer business.

Ratajczak, M. (2012). Finansyzacja gospodarki. Ekonomista 3: 281-302.

Ratajczak, M. (2014). Ekonomia i edukacja ekonomiczna w dobie finansyzacji gospodarki. Ekonomista 2: 207-219.

Ratajczak, M. (2017). Wzrost gospodarczy w warunkach finansyzacji gospodarki. Studia Oeconomica Posnaniensia 5(5): 23-37.

Remlein, M. (2015). Wpływ finansyzacji gospodarki na wyniki finansowe polskich przedsiębiorstw. Zeszyty Naukowe Uniwersytetu Szczecińskiego. Finanse, Rynki Finansowe, Ubezpieczenia 77: 169-180.

Rossmann, P., Greenfield, G. (2006). Financialization: new routes to profit, new challenges for trade unions. Labour Education. The Quarterly Review of the ILO Bureau for Workers' Activities 142: 1-9.

Rynio, D. (2010). Atrakcyjność lokalizacji inwestycji zagranicznych w metropolii. Acta Universitatis Lodziensis. Folia Oeconomica 246: 105-115.

Sawkowicz, P. (2003). Zadłużenie samorządów - podstawy teoretyczne i doświadczenie Europy Zachodniej. Finanse Komunalne 5: 5-17.

Socha, Ł.M. (2016). Ufinansowienie spółek notowanych na GPW w Warszawie SA w latach 20052012, [w:] A. Gemzik-Salwach, K. Opolski (red.), Finansjalizacja. Wpływ na gospodarkę i społeczeństwo. Warszawa: CeDeWu: 117-126. 
Socha, B., Urban, D. (2018). The Financialization of Companies Listed on the Warsaw Stock Exchange - the Sector Analysis. Annales Universitatis Mariae Curie-Skłodowska, Lublin-Polonia, Sectio H 52(4): 93-102.

Spoz, A. (2016). Wpływ finansyzacji na działalność i sprawozdawczość przedsiębiorstw. Prace Naukowe Uniwersytetu Ekonomicznego we Wrocławiu 436: 270-277.

Swianiewicz, P. (2011). Finanse samorządowe - koncepcje, realizacja, polityki lokalne. Warszawa: Wydawnictwo Municipium.

Swianiewicz, P. (2014). Ocena podziału terytorialnego państwa z uwzględnieniem efektywności funkcjonowania urzędów organów jednostek samorządu terytorialnego - wnioski i rekomendacje. Warszawa: Ministerstwo Administracji i Cyfryzacji.

Szczepankowski, P. (2016). Finansyzacja przedsiębiorstw przemysłowych w Polsce. Kwartalnik Nauk o Przedsiębiorstwie 1: 31-47.

Szunke, A. (2014). The role of financialization in banking sector instability. Journal of Economics \& Management 16: 97-111.

Tetla, M. (2016). Dług publiczny jednostek samorządu terytorialnego w latach 2012-2014 i sposoby jego ograniczania. Studia Ekonomiczne. Zeszyty Naukowe Uniwersytetu Ekonomicznego w Katowicach: 131-140.

Waligóra, K. (2013). Zadłużenie jednostek samorządu terytorialnego w aspekcie realizacji projektów współfinansowanych ze środków Unii Europejskiej (na przykładzie Białegostoku), [w:] M. Poniatowicz (red.), Finanse samorządu terytorialnego w niestabilnym otoczeniu. Białystok: Wydawnictwo Uniwersytetu w Białymstoku.

Waliszewski, K. (2016). Financialization of the economy and the need for personal finance advisory services. Financial Internet Quarterly "e-Finanse" 12(2): 13-23.

Włodarczyk, B. (2018). Rynek surowców a ryzyko bankowe (w ujęciu ryzyka rynkowego i kredytowego). Olsztyn: Wydawnictwo UWM.

\section{THE FINANCIALIZATION OF LOCAL SELF-GOVERNMENT UNITS BASED ON THE EXAMPLE OF METROPOLITAN CITIES IN POLAND}

\section{Summary}

The article addresses the problem of the process of the financialization of local self-government units. First of all, the characterization of this phenomenon is made, then a measurement proposal is presented, using the analysis of the structure of balance sheet assets and liabilities and the debt of metropolitan cities in 2007-2017. The research results lead to inconclusive conclusions. In the early years of the research period, increasing indicators of the financializaton of assets and liabilities, as well as an increase in debt, were observed, which indicated the symptoms of the financial crisis. In the second part of the research period, the values of the indicators characterizing the indebtedness of metropolitan cities decreased, but the financialization assets and liabilities ratios increased slightly. The final assessment of these trends will be possible in the longer term and will require consideration of other, immeasurable factors, such as a city's financial policy, statutory law, and the quality of public services provided by municipalities.

Keywords: financialization; local self-government units; metropolitan cities 
